\title{
ДИАЗОЛЫ, СОДЕРЖАЩИЕ ДИАЗОФУНКЦИЮ, КАК КЛЮЧЕВЫЕ ИНТЕРМЕДИАТЫ В СИНТЕЗЕ НОВЫХ ГЕТЕРОЦИКЛИЧЕСКИХ СОЕДИНЕНИЙ
}

\author{
Е.В. Садчикова ${ }^{1,2}$, Д.Л. Алексеева', А.Ю. Петров² \\ ${ }^{1}$ Кафедра технологии органического синтеза, химико-технологический институт, \\ ФГАОУ ВО УрФУ имени первого Президента России Б.Н. Ельцина, \\ 620002, Российская Федерация, г. Екатеринбург, ул. Мира, д. 28. \\ ${ }^{2}$ Кафедра фармации и химии, фармацевтический факультет, ФГБОУ ВО УГМУ, \\ 620026, Российская Федерация, г. Екатеринбург, ул. Декабристов, д. 32.
}

DOI: 10.19163/MedChemRussia2021-2021-425

E-mail: selena-ekb@rambler.ru

Несмотря на то, что в последние годы в области разработки и производства современных лекарственных средств начинают доминировать биофармацевтические технологии, химический синтез малых органических молекул сохраняет свою актуальность.

Для реализации стратегии направленного синтеза несомненный интерес представляет изучение методов получения и свойств гетероциклических производных, содержащих в своей структуре диазофункцию, поскольку они обладают широким потенциалом, объединяющим в себе синтетические возможности как ароматических солей диазония, так и алифатических диазосоединений [1]. Полученные на основе диазоазолов и используемые в настоящее время в клинической практике соединения с противовирусной («Триазавирин») и противоопухолевой («Дакарбазин», «Темозоломид») активностью придают еще бо́льшую практическую значимость продолжению исследований в данной области.

В докладе представлены результаты изучения методов синтеза и идентификации солей диазония 1 и диазосоединений 2 в ряду имидазолов и пиразолов, а также их синтетические возможности, позволившие получить и исследовать свойства широкого ряда разнообразных гетероциклических производных 3-11.
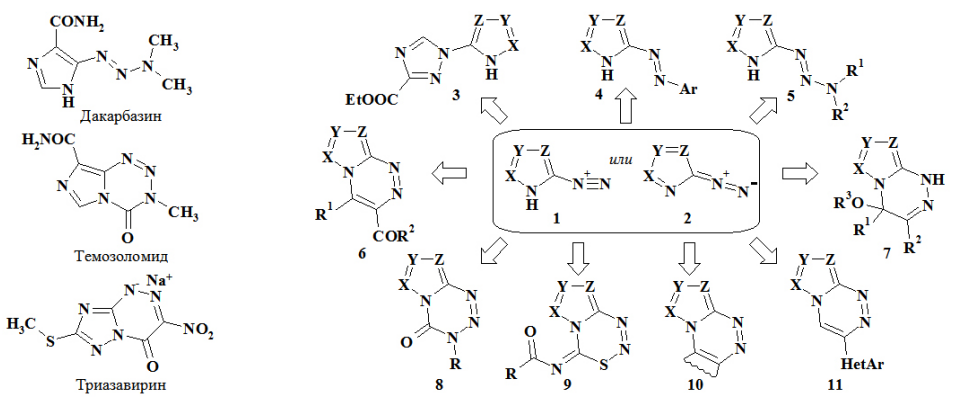

Литература

[1]. Мокрушин В.С. Химия гетероциклических диазосоединений / В.С. Мокрушин,

Е.В. Садчикова. - СПб.: Проспект Науки, 2013. - 224 с. 